\title{
Cloning, Purification, Crystallization and Preliminary X-Ray Diffraction Studies of Periplasmic Glucose Binding Protein of Pseudomonas putida CSV86
}

\author{
Suman Pandey, Arnab Modak, Prashant S. Phale, Prasenjit Bhaumik* \\ Department of Biosciences and Bioengineering, Indian Institute of Technology Bombay, Mumbai, India \\ Email: " pbhaumik@iitb.ac.in
}

Received 23 February 2015; accepted 11 March 2015; published 17 March 2015

Copyright (C) 2015 by authors and Scientific Research Publishing Inc.

This work is licensed under the Creative Commons Attribution International License (CC BY).

http://creativecommons.org/licenses/by/4.0/

(c) (i) Open Access

\begin{abstract}
Biochemical data and genomic analysis indicate the involvement of a putative $\mathrm{ABC}$ transporter for glucose transport in Pseudomonas putida CSV86. The periplasmic solute binding proteins are known to confer substrate specificity to the ABC transporters by binding specifically to the substrate and transferring them to their cognate inner membrane transport assembly. Periplasmic glucose binding protein from Pseudomonas putida CSV86 (ppGBP) was found to be glucose specific. The gene encoding ppGBP was cloned. Recombinant ppGBP was overexpressed and purified to homogeneity. The purified recombinant protein showed glucose binding activity of $752 \mathrm{pmol} / \mathrm{mg}$ of protein and was crystallized as a complex with glucose. The crystal diffracted to 1.7 Å resolution using home X-ray source. Preliminary analysis of diffraction data showed that the crystals belonged to space group $P 2{ }_{1} 2_{1} 2$ with unit-cell parameters $a=102.56, b=119.2, c=66.65 \AA$ and $\alpha=$ $\beta=\gamma=90^{\circ}$. Matthews coefficient calculation showed the presence of two molecules in the asymmetric unit with solvent content of $45.7 \%$.
\end{abstract}

\section{Keywords}

Periplasmic Glucose Binding Protein, Pseudomonas, Crystallization

\footnotetext{
*Corresponding author.
}

How to cite this paper: Pandey, S., Modak, A., Phale, P.S. and Bhaumik, P. (2015) Cloning, Purification, Crystallization and Preliminary X-Ray Diffraction Studies of Periplasmic Glucose Binding Protein of Pseudomonas putida CSV86. Advances in Bioscience and Biotechnology, 6, 164-171. http://dx.doi.org/10.4236/abb.2015.63016 


\section{Introduction}

In all the three kingdoms of life, substrates are transported across the biological membrane through ABC transporters. Solute binding proteins (SBPs) are the periplasmic component of ABC transporters that bind to the substrate with very high affinity and transport it to the transmembrane domain of the transporter [1] [2]. SBPs are often involved in transport and signal transduction in association with membrane proteins [3]. SBPs are bacterial receptors that specifically recognize ligand and serve as intermediary periplasmic receptors for transport (via ABC transport systems). They are also involved in chemotaxis and quorum sensing [4] [5]. The concentration of SBPs in the periplasm $(\sim 0.1-1 \mathrm{mM})$ is much higher than the membrane transport assembly and extracellular solutes (under most circumstances $\leq 1 \mu \mathrm{M}$ ) [3]. It is known that the efficiency of solute uptake is mainly due to the high ligand binding affinity (from $\mathrm{nM}$ to $\mu \mathrm{M}$ range) of the SBPs [6].

The functional SBPs are monomeric proteins ranging from 25 - $70 \mathrm{kDa}$ in size and are structurally composed of two domains joined by a hinge region, each domain having a core of few $\beta$ sheets surrounded by $\alpha$ helices. The substrate binding pocket is located in between the two domains [7] [8]. These SBPs are in the open conformation in the absence of the substrate [8] and upon ligand binding the domains come together forming the closed conformation. Ligand induced conformation change in SBP structures is known as the "venus fly trap mechanism" [9]. Based on the differences in the core $\beta$-sheet topology, the secondary structure connectivity and the hinge region, SBPs were classified into two groups [10]. Based on structure and sequence alignment, SBPs have been recently divided into six clusters (A to F) [3]. Despite of very low sequence identities among the SBPs, their overall structural fold is similar with a diverse substrate binding pocket. Because of poor sequence identity among SBPs, structure prediction still remains challenging and determination of crystal structure is essential in order to understand the substrate binding mechanism of SBPs from different species.

Sugar transport in bacteria can be mediated both by energy independent membrane permeation as well as by energy dependent accumulation against a concentration barrier [11]. In Pseudomonas, there are two pathways for glucose transport, a low affinity, direct oxidative pathway and a high affinity, phosphorylative pathway [12]. Pseudomonas putida CSV86 (hence onwards referred as CSV86), utilizes glucose only by the intracellular high affinity phosphorylative pathway [12]. The glucose transport system is repressed in presence of aromatics and organic acids and is induced in the presence of glucose [13] [14]. In CSV86, the gene encoding outer membrane glucose porin (OprB) [14] and periplasmic glucose-binding protein (ppGBP) [15] are arranged in an operonic fashion along with the putative genes for inner membrane ABC transporter [16]. For glucose transport systems, the reported glucose binding affinity is as high as $0.08 \mu \mathrm{M}$ for Thermus thermophilus glucose/galactose binding protein (ttGBP) and $0.92 \mu \mathrm{M}$ for E. coli glucose/galactose binding protein (ecGBP). The ppGBP also shows high affinity for glucose $\left(K_{\mathrm{d}}=0.3 \mu \mathrm{M}\right.$; Modak et al., unpublished) and confers the specificity of glucose transport to this putative ABC sugar transporter. Mechanism of sugar transport in Pseudomonas sp. is not well understood due to lack of biochemical and structural information [17]. Therefore, structural studies of the glucose transport proteins would help in better understanding of the sugar transport systems in Pseudomonas sp. There are more than hundred Protein Data Bank (PDB) entries for solute binding proteins with only few entries for monosaccharide and oligosaccharide binding proteins [3]. No structure is available yet for the periplasmic sugar binding proteins from any Pseudomonas sp. Recently, the structural model of ppGBP was predicted by homology modeling. The predicted structure showed maximum structural similarity to ttGBP despite of having only $27 \%$ sequence identity. Residues of ppGBP involved in glucose binding were predicted and importance of some of the predicted residues was shown by site directed mutagenesis [18]. SBPs of sugars such as ecGBP and ttGBP show affinity for both glucose and galactose [3]. But biochemical characterization of both native and recombinant ppGBP suggested it to be a glucose specific protein having only around $15 \%$ inhibition of $\left[{ }^{14} \mathrm{C}\right]$-glucose binding activity in presence of 100 fold molar excess of unlabelled galactose [15] [18]. Being a C4 epimer of glucose, galactose could not completely or significantly inhibit the $\left[{ }^{14} \mathrm{C}\right]$-glucose binding activity of ppGBP. This experimental evidence suggests that the sugar binding pocket in ppGBP is probably not similar to that of ttGBP, ecGBP or other reported dual specific SBPs of sugars. Therefore, structural studies are essential to get an insight into the binding pocket of ppGBP leading to a better understanding of substrate specificity of ppGBP. The structure of ppGBP would also be useful in elucidating the substrate binding mechanism of SBPs in other Pseudomonas sp. In this study ppGBP, a periplasmic component of the glucose ABC transport system in CSV86 has been cloned, overexpressed and purified to homogeneity. The recombinant protein with high glucose binding activity was crystallized as a complex with glucose and the crystals belonging to space group $P 2{ }_{1} 2{ }_{1} 2$ dif- 
fracted to $1.7 \AA$ Aresolution.

\section{Materials and Methods}

\subsection{Cloning and Expression of ppGBP}

The $g b p$ gene lacking periplasmic targeting sequence was PCR-amplified from P. putida CSV86 chromosomal DNA using forward and reverse primers GBP-F (5'CCGGAATTCCATATGGCCGACAATCCTGGCACC3') and GBP-R (5'CCGGAATTC CTACCTGGCCGCCTTGATGC3'), respectively. Underlined bases indicate the restriction sites used for cloning. The PCR amplified products digested with NdeI and EcoRI were cloned into pET-28a vector. The recombinant ppGBP construct lacked the signal sequence and had an N-terminal $\mathrm{His}_{6}$ tag with a thrombin cleavage site. Escherichia coli DH5 $\alpha$ cells were transformed with the ppGBP expression construct and grown on Luria-Bertani (LB) broth agar plates containing $30 \mu \mathrm{g} / \mathrm{ml}$ of kanamycin. The positive clones were verified by DNA sequencing. The resulting expression plasmid was transformed into the E. coli BL21(DE3) expression host.

For protein expression, a colony of E. coli BL21(DE3) containing ppGBP expression plasmid was inoculated in $10 \mathrm{ml} \mathrm{LB}$ medium containing kanamycin $(30 \mu \mathrm{g} / \mathrm{ml})$ and the culture was grown overnight at $37^{\circ} \mathrm{C}$. After that the culture was transferred to 1 liter LB medium supplemented with $30 \mu \mathrm{g} / \mathrm{ml}$ kanamycin and allowed to grow at $37^{\circ} \mathrm{C}$ with shaking until an optical density $\left(\mathrm{OD}_{600}\right)$ of 1.0 was reached. At that point, overexpression of the recombinant ppGBP was induced with $100 \mu \mathrm{M}$ isopropyl-d-1-thiogalactopyranoside (IPTG) at $37^{\circ} \mathrm{C}$ for four hours. Cells were harvested by centrifugation at $7000 \mathrm{~g}$ for $10 \mathrm{~min}$ at $4^{\circ} \mathrm{C}$.

\subsection{Purification of ppGBP}

Purification of ppGBP was done at $4^{\circ} \mathrm{C}$. The cell pellet $(6.0 \mathrm{~g})$ was resuspended in $30 \mathrm{ml}$ of cold buffer $A(10$ $\mathrm{mM}$ Tris-HCl, $\mathrm{pH} 7.5$ and $1 \mathrm{mM} \mathrm{MgCl}_{2}$ ). The cells were lysed by ultrasonication with 5 cycles/g wet weight of cells and each cycle comprised of 15 pulses ( $1 \mathrm{sec}$ on and $1 \mathrm{sec}$ off) at 10 watt output. The cell debris was removed by centrifugation at 30,000 g for $30 \mathrm{~min}$ and the supernatant was filtered through $0.45 \mu \mathrm{M}$ membrane. In the first step of purification, the filtered supernatant was loaded onto a $10 \mathrm{ml}$ Ni-NTA His trap FF column (GE Healthcare) equilibrated with buffer $A$. After washing the unbound protein, ppGBP was eluted with a $100 \mathrm{ml}$ linear gradient of $0-250 \mathrm{mM}$ imidazole prepared in buffer $A$. The eluted protein sample was analyzed on $12 \%$ SDS-PAGE and the ppGBP was found to be eluted in the range of $160-180 \mathrm{mM}$ imidazole. Subsequently, ppGBP containing fractions were pooled and concentrated. The protein was loaded onto a $120 \mathrm{ml}$ Superdex 200 16/60 gel filtration column (GE Healthcare) equilibrated with buffer $A$. Protein was eluted at a flow rate of 0.3 $\mathrm{ml} / \mathrm{min}$ and $1.0 \mathrm{ml}$ fractions were collected. The fractions containing pure ppGBP were pooled and concentrated to $20 \mathrm{mg} / \mathrm{ml}$ by centrifugal ultrafiltration unit with $10 \mathrm{kDa}$ molecular weight cutoff membrane. The concentration of the protein was measured using Bradford's method [19]. The purity of ppGBP after gel filtration column was analyzed on $12 \%$ SDS-PAGE [20].

\section{3. $\left[{ }^{14} \mathrm{C}\right]$-Glucose Binding Assay of ppGBP}

$\left[{ }^{14} \mathrm{C}\right]$-Glucose binding activity was measured using the method as described earlier [15] [18] [21]. Binding mixture $(1 \mathrm{ml})$ contained protein (crude extract: $100 \mu \mathrm{g}$, affinity chromatography purified ppGBP: $2.5 \mu \mathrm{g}$, gel filtration purified ppGBP: $2.5 \mu$ g, respectively) and $\left[{ }^{14} \mathrm{C}\right]$-glucose $(500 \mathrm{nM}$, sp. act. $140 \mathrm{mCi} / \mathrm{mmol})$ in binding buffer (10 mM Tris-HCl, $1 \mathrm{mM} \mathrm{MgCl}_{2}$, $\mathrm{pH}$ 7.5). Mixture was incubated for $5 \mathrm{~min}$ at $30^{\circ} \mathrm{C}$ and rapidly filtered through pre-moistened PVDF membranes ( $0.45 \mu \mathrm{M}$, Pall Life Sciences). Filters were washed twice with binding buffer, air-dried overnight at $30^{\circ} \mathrm{C}$, mixed vigorously in $2 \mathrm{ml}$ scintillation cocktail [PPO $(0.4 \%)$ and POPOP $(0.025 \%)$ in toluene (scintillation grade)] and radioactivity was measured using liquid scintillation counter (Rackbeta LKB1209). Binding activity was expressed as pmoles of $\left[{ }^{14} \mathrm{C}\right]$-glucose bound per mg of protein (Table 1). Binding reaction mixture without protein was used as control and the values were subtracted from the experimental $\left[{ }^{14} \mathrm{C}\right]$-glucose binding values.

\subsection{Circular Dichroism Spectroscopy}

Far-UV CD spectra of recombinant ppGBP and native ppGBP in the binding buffer were recorded between 198 
Table 1. Purification table of ppGBP.

\begin{tabular}{|c|c|c|c|c|c|}
\hline $\begin{array}{c}\text { Sample after } \\
\text { purification step }\end{array}$ & $\begin{array}{l}\text { Total protein used } \\
\text { per reaction }(\mu \mathrm{g})\end{array}$ & $\begin{array}{l}\text { Total activity } \\
\text { (pmol) }\end{array}$ & $\begin{array}{l}\text { Specific activity } \\
\text { (pmol/mg) }\end{array}$ & $\begin{array}{c}\text { Fold } \\
\text { purification }\end{array}$ & $\begin{array}{l}\text { Yield } \\
\text { (\%) }\end{array}$ \\
\hline Cell free extract & 100 & 6.25 & 62.5 & 1 & 100 \\
\hline Ni-NTA affinity chromatography & 2.5 & 0.56 & 224 & 3.58 & 86.8 \\
\hline $\begin{array}{l}\text { Superdex } 200 \text { gel filtration } \\
\text { chromatography }\end{array}$ & 2.5 & 1.88 & 752 & 12.03 & 38.2 \\
\hline
\end{tabular}

and $260 \mathrm{nM}$ at $25^{\circ} \mathrm{C}$ in a $0.1 \mathrm{~cm}$ path length quartz cuvette (volume $200 \mu \mathrm{l}$; Hellma GmBH \& Co., KG, Müllheim, Germany) using a JASCO J-810 Peltier spectropolarimeter (Jasco, Gross-Umstadt, Germany). The parameters were: response, 2 s; sensitivity, 100 millidegrees; speed, $100 \mathrm{nM} / \mathrm{min}$; average of three scans. Raw data was processed by smoothing and subtraction of spectra obtained using binding buffer alone. Ellipticity values (millidegrees) were recorded as a function of wavelength.

\subsection{Crystallization of ppGBP}

Pure ppGBP after gel filtration was concentrated up to $20 \mathrm{mg} / \mathrm{ml}$ and used for crystallization. Before setting crystallization trials, protein was incubated with 5 molar excess of glucose on ice for 30 min to prepare ppGBPglucose complex. Crystallization screening of ppGBP-glucose complex was done using hanging drop vapor diffusion method at $295 \mathrm{~K}$. Commercial screen solutions from Qiagen (PEGs Suite and JCSG Core I Suite) and Molecular Dimensions (JCSG plus Screen) were used for crystallization trials. Initial crystallization screens were setup by mixing $1 \mu \mathrm{l}$ of protein with $1 \mu \mathrm{l}$ of reservoir solution and equilibrating the crystllization drops against $300 \mu \mathrm{l}$ of reservoir solution. After a month of incubation of the crystallization trays, the first crystal of ppGBP-glucose complex was observed in condition no. 90 of JCSG Core I Suite consisting of 0.1 M phosphate buffer $\mathrm{pH} 4.2$ and $2 \mathrm{M}$ ammonium sulphate. The crystallization condition was further optimized and the best crystals appeared after two days in a condition having $0.1 \mathrm{M}$ phosphate buffer $\mathrm{pH} 4.6$ and $2 \mathrm{M}$ ammonium sulphate and they grew to a size of $0.4 \times 0.2 \times 0.2 \mathrm{~mm}$ after a week of incubation at $295 \mathrm{~K}$.

\subsection{X-Ray Diffraction Data Collection and Processing}

One of the glucose bound ppGBP crystals grown in $0.1 \mathrm{M}$ phosphate buffer pH 4.6 and $2 \mathrm{M}$ ammonium sulphate was cryoprotected using the same reservoir solution also containing 30\% glycerol and used for X-ray diffraction data collection. The crystal was briefly transferred to the cryoprotectant solution and then was flash-cooled in the liquid nitrogen-gas stream at $100 \mathrm{~K}$. Diffraction data were collected at Advanced Centre for Treatment, Research and Education in Cancer (ACTREC, Navi Mumbai, India) using a Bruker MICROSTAR copper rotating anode X-ray generator equipped with a MAR345 image-plate detector. The diffraction data was collected using $1.5418 \AA$ wavelength X-ray by rotating the crystal $0.5^{\circ}$ per image with an exposure time of 2 min and $120 \mathrm{~mm}$ crystal to detector distance. The diffraction images were indexed and integrated using the programs XDS [22]. The intensities were converted to structure factors with the program modules F2MTZ and CAD of CCP4 [23]. The data collection and processing statistics are presented in Table 2.

\section{Results and Discussion}

The gene encoding ppGBP protein of CSV86 was cloned into pET-28a vector. The coding regions of cloned $g b p$ gene lacked periplasmic signal sequence. The expressed ppGBP is a 419 amino acids containing polypeptide with N-terminal $\mathrm{His}_{6}$ tag with a thrombin cleavage site and has $45 \mathrm{kDa}$ theoretical molecular weight. Recombinant ppGBP was overexpressed in E. coli and purified to homogeneity using affinity followed by size-exclusion chromatography. SDS-PAGE analysis (Figure 1) of purified ppGBP sample showed a single band with molecular weight of around $45 \mathrm{kDa}$. The protein sample also eluted as a monomer from the gel filtration column. The glucose binding activity of the highly pure protein was found to be $752 \mathrm{pmol} / \mathrm{mg}$ of the protein measured by $\left[{ }^{14} \mathrm{C}\right]$-glucose binding assay (Table 1 ). Similar glucose binding activity was also reported for the native ppGBP [18]. The CD spectra of the recombinant ppGBP were also found to be similar to the native ppGBP having the signal sequence (Figure 2). Glucose binding activity and CD spectra of recombinant ppGBP indicates that the 
Table 2. Data collection and processing statistics of ppGBP crystal.

\begin{tabular}{|c|c|}
\hline Wavelength $(\AA)$ & 1.5418 \\
\hline Temperature (K) & 100 \\
\hline Detector type & MAR 345 image plate \\
\hline Detector to crystal distance (mm) & 120 \\
\hline Oscillation range per image $\left({ }^{\circ}\right)$ & 0.5 \\
\hline Total rotation range $\left({ }^{\circ}\right)$ & 180 \\
\hline Exposure time per frame (s) & 120 \\
\hline Space group & $P 22_{1} 2$ \\
\hline $\begin{array}{c}\text { Unit-cell parameters } \\
a, b, c(\AA) \\
\alpha, \beta, \gamma\left({ }^{\circ}\right)\end{array}$ & $\begin{array}{c}a=102.6, b=119.3, c=66.6 \\
\alpha=\beta=\gamma=90\end{array}$ \\
\hline Mosaicity $\left(^{\circ}\right)$ & 0.3 \\
\hline Resolution $(\AA)$ & $40-1.7(1.8-1.7)$ \\
\hline Observed reflections & $639,079(97,092)$ \\
\hline Unique reflections & $85,004(12,722)$ \\
\hline Redundancy & $7.5(7.6)$ \\
\hline Completeness (\%) & $93.9(90.2)$ \\
\hline Average I/ $\sigma(\mathrm{I})$ & $30.80(5.7)$ \\
\hline$R_{\text {meas }}(\%)$ & $5.6(41.4)$ \\
\hline $\mathrm{CC}_{1 / 2}$ & $1.0(0.93)$ \\
\hline Overall B factor from Wilson plot $\left(\AA^{2}\right)$ & 23.5 \\
\hline
\end{tabular}

Values for the outer resolution shell are given in parentheses.

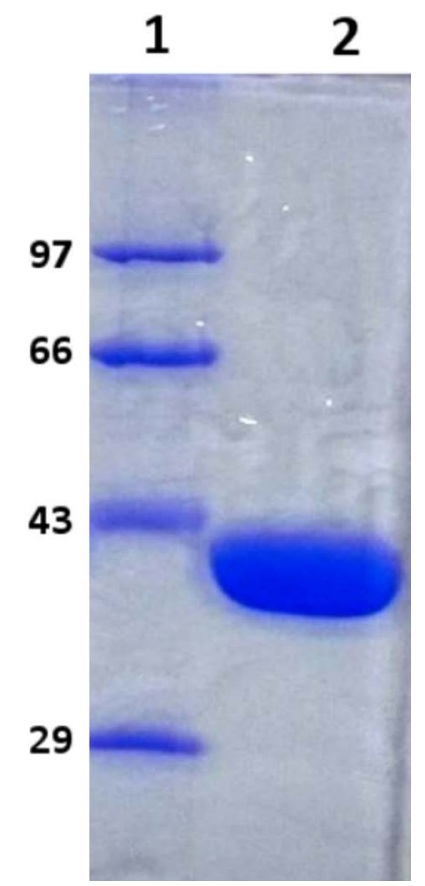

Figure 1. SDS-PAGE showing purity of ppGBP obtained after gel filtration chromatography. Lane 1 shows molecular weight markers $(\mathrm{kDa})$ and lane 2 shows the purified ppGBP. 
protein is similar to completely folded native ppGBP and functional without signal sequence.

Several crystallization screens of ppGBP-glucose complex were set up using commercially available crystallization solutions. After optimization of $\mathrm{pH}$ of the initial hit, rod shaped big crystals (Figure 3) were seen within two days in a condition consisting of $0.1 \mathrm{M}$ phosphate buffer $\mathrm{pH} 4.6$ and $2 \mathrm{M}$ ammonium sulphate. Cryoprotectants were screened and $30 \%$ glycerol containing mother liquor was suitable for freezing the crystals. A single ppGBP crystal was used for diffraction data collection and the crystal diffracted to a resolution of $1.7 \AA$ (Figure 4) using home X-ray source. The data were indexed, and scaled using XDS program [22]. Analysis of systematic absences of the diffraction data indicated that the crystal belonged to orthorhombic $P 2{ }_{1} 2{ }_{1} 2$ space group with unit cell parameters $a=102.56, b=119.2, c=66.65 \AA$ and $\alpha=\beta=\gamma=90^{\circ}$. The data collection and processing statistics are presented in Table 2. Calculated Mathews coefficient $\left(V_{\mathrm{M}}\right)$ value of $2.26 \AA^{3} \cdot \mathrm{Da}^{-1}$ [24] suggested presence of two protein molecules in the asymmetric unit of ppGBP crystals containing $45.7 \%$ solvent. Structure of ttGBP (PDB ID = 2B3B) has the highest sequence identity (27.0\%) with the ppGBP and will be used as a template for obtaining initial phases by molecular replacement. Structure of ppGBP along with mutagenesis data will help us in understanding the structural basis of sugar specificity of this protein in P. putida CSV86 and solute binding proteins in other Pseudomonas sp.

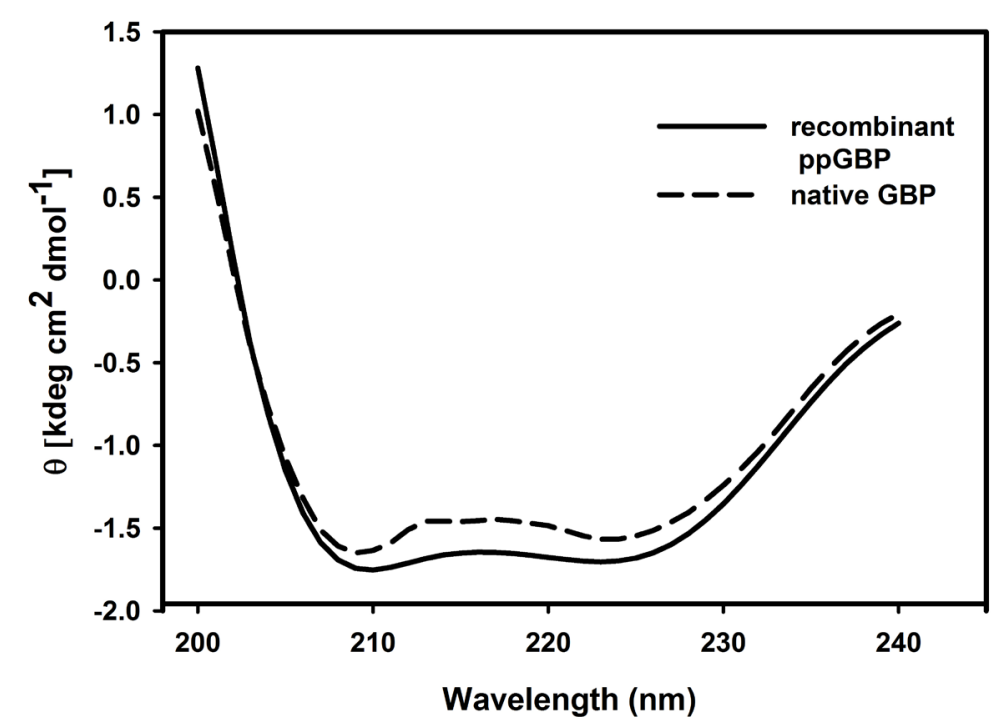

Figure 2. The far-UV CD spectroscopic analysis of recombinant ppGBP (solid line) and native PpGBP (dotted line).

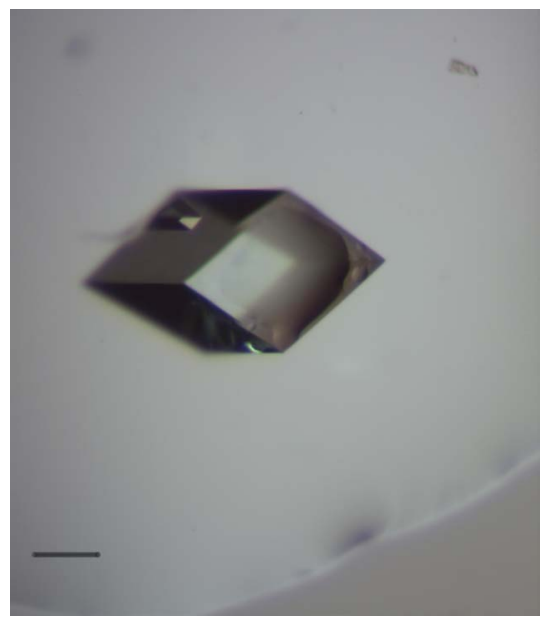

Figure 3. Crystal of ppGBP-glucose complex. Approximate dimensions of the crystal is $0.4 \times 0.2 \times 0.2 \mathrm{~mm}$. The scale bar represents $0.1 \mathrm{~mm}$. 


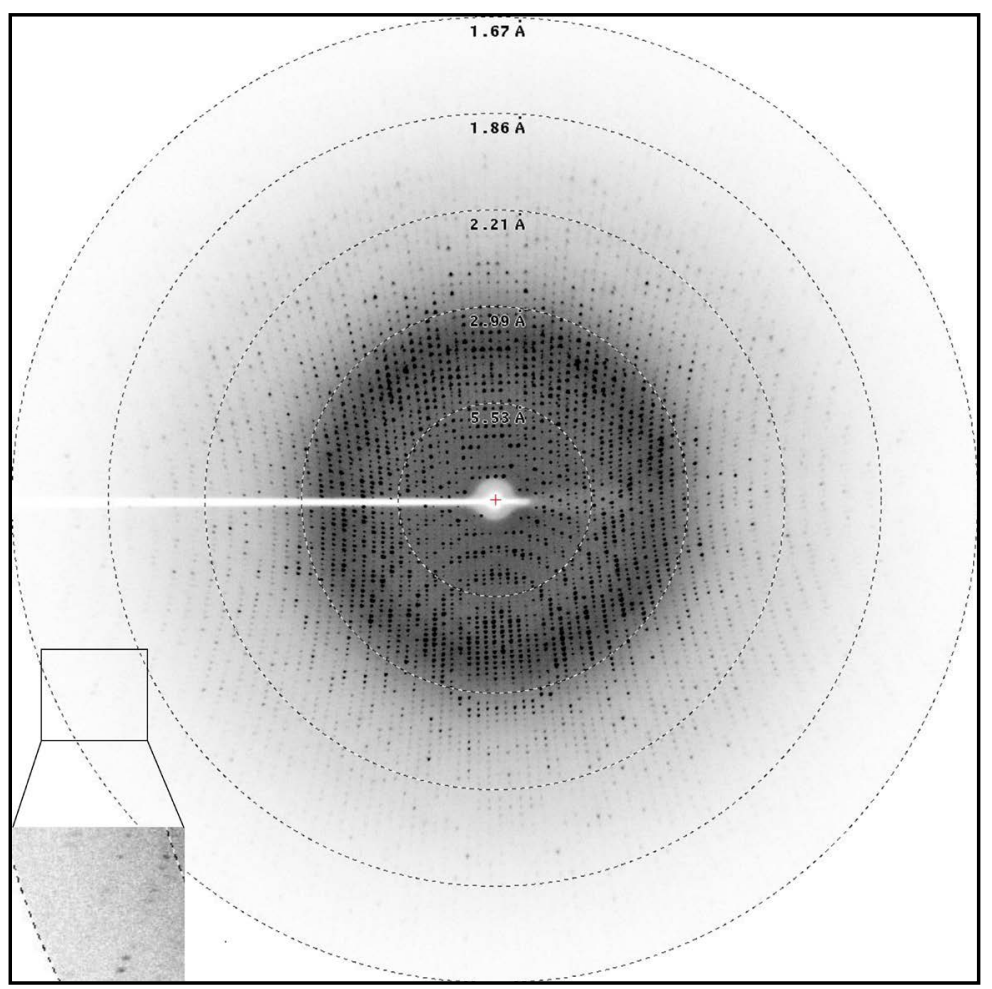

Figure 4. Diffraction pattern obtained from glucose bound ppGBP crystal using home X-ray source at ACTREC, Navi Mumbai, India. The crystal diffracted to a high-resolution limit of $1.7 \AA$ (inset).

\section{Acknowledgements}

We would like to express our gratitude towards Mrs. Ulka U. Sawant and Dr. Ashok K. Varma from ACTREC (Navi Mumbai, India) for providing us with access to the X-ray diffractometer. Ph.D. fellowship for Ms. Suman Pandey and Arnab Modak by Council of Scientific and Industrial Research (CSIR), India is acknowledged. The work is supported by Ramalingaswami Re-entry Fellowship and research grant to Dr. Prasenjit Bhaumik from Department of Biotechnology, Ministry of Science and Technology, India. Research grant to Dr. Prashant S. Phale from Department of Science and Technology, Ministry of Science and Technology, India is also acknowledged.

\section{References}

[1] Biemans-Oldehinkel, E., Doeven, M.K. and Poolman, B. (2006) ABC Transporter Architecture and Regulatory Roles of Accessory Subunits. FEBS Letters, 580, 1023-1035. http://dx.doi.org/10.1016/j.febslet.2005.11.079

[2] Higgins, C.F. (1992) ABC Transporters: From Microorganisms to Man. Annual Review of Cell Biology, 8, 67-113. http://dx.doi.org/10.1146/annurev.cb.08.110192.000435

[3] Berntsson, R.P., Smits, S.H., Schmitt, L., Slotboom, D.J. and Poolman, B. (2010) A Structural Classification of Substrate-Binding Proteins. FEBS Letters, 584, 2606-2617. http://dx.doi.org/10.1016/j.febslet.2010.04.043

[4] Chen, X., Schauder, S., Potier, N., Van Dorsselaer, A., Pelczer, I., Bassler, B.L. and Hughson, F.M. (2002) Trapping the Transition State of an ATP-Binding Cassette Transporter: Evidence for a Concerted Mechanism of Maltose Transport. Nature, 415, 545-549. http://dx.doi.org/10.1038/415545a

[5] Tam, R. and Saier, M.H. (1993) Structural, Functional, and Evolutionary Relationships among Extracellular SoluteBinding Receptors of Bacteria. Microbiological Reviews, 57, 320-346.

[6] Wilkinson, T. and Verschueren, K.H.G. (2003) ABC Proteins: From Bacteria to Man. In: Holland, B., Kuchler, K., Cole, S.P. and Higgins, C., Eds., Elsevier Science and Technology Books, Academic Press, London, 187-208.

[7] Cuneo, M.J., Changela, A., Warren, J.J., Beese, L.S. and Hellinga, H.W. (2006) The Crystal Structure of a Thermophilic Glucose Binding Protein Reveals Adaptations That Interconvert Mono and Di-Saccharide Binding Sites. Journal 
of Molecular Biology, 362, 259-270. http://dx.doi.org/10.1016/j.jmb.2006.06.084

[8] Quiocho, F.A. and Ledvina, P.S. (1996) Atomic Structure and Specificity of Bacterial Periplasmic Receptors for Active Transport and Chemotaxis: Variation of Common Themes. Molecular Microbiology, 20, 17-25. http://dx.doi.org/10.1111/j.1365-2958.1996.tb02484.x

[9] Mao, B., Pear, M.R., McCammon, J.A. and Quiocho, F.A. (1982) Hinge-Bending in L-Arabinose-Binding Protein. The “Venus’s-Flytrap” Model. Journal of Biological Chemistry, 257, 1131-1133.

[10] Fukami-Kobayashi, K., Tateno, Y. and Nishikawa, K. (1999) Domain Dislocation: A Change of Core Structure in Periplasmic Binding Proteins in Their Evolutionary History. Journal of Molecular Biology, 286, 279-290. http://dx.doi.org/10.3390/life3010149

[11] Phibbs Jr., P.V. and Eagon, R.G. (1970) Transport and Phosphorylation of Glucose, Fructose, and Mannitol by Pseudomonas aeruginosa. Archives of Biochemistry and Biophysics, 138, 470-482. http://dx.doi.org/10.1016/0003-9861(70)90371-1

[12] Basu, A. and Phale, P.S. (2006) Inducible Uptake and Metabolism of Glucose by the Phosphorylative Pathway in Pseudomonas putida CSV86. FEMS Microbiology Letters, 259, 311-316. http://dx.doi.org/10.1111/j.1574-6968.2006.00285.x

[13] Basu, A., Apte, S.K. and Phale, P.S. (2006) Preferential Utilization of Aromatic Compounds over Glucose by Pseudomonas putida CSV86. Applied and Environmental Microbioogy, 72, 2226-2230. http://dx.doi.org/10.1128/AEM.72.3.2226-2230.2006

[14] Shrivastava, R., Basu, B., Godbole, A., Mathew, M.K., Apte, S.K. and Phale, P.S. (2011) Repression of the GlucoseInducible Outer-Membrane Protein OprB during Utilization of Aromatic Compounds and Organic Acids in Pseudomonas putida CSV86. Microbiology, 157, 1531-1540. http://dx.doi.org/10.1099/mic.0.047191-0

[15] Basu, A., Shrivastava, R., Basu, B., Apte, S.K. and Phale, P.S. (2007) Modulation of Glucose Transport Causes Preferential Utilization of Aromatic Compounds in Pseudomonas putida CSV86. Journal of Bacteriology, 189, 7556-7562. http://dx.doi.org/10.1128/JB.01235-07

[16] Phale, P.S., Paliwal, V., Raju, S.C., Modak, A. and Purohit, H.J. (2013) Genome Sequence of Naphthalene-Degrading Soil Bacterium Pseudomonas putida CSV86. Genome Announcement, 1, e00234-12. http://dx.doi.org/10.1128/genomeA.00234-12

[17] Li, H., Luo, Y.F., Williams, B.J., Blackwell, T.S. and Xie, C.M. (2012) Structure and Function of OprD Protein in Pseudomonas aeruginosa: From Antibiotic Resistance to Novel Therapies. International Journal of Medical Microbiology, 302, 63-68. http://dx.doi.org/10.1016/j.ijmm.2011.10.001

[18] Modak, A., Bhaumik, P. and Phale, P.S. (2014) Periplasmic Glucose-Binding Protein from Pseudomonas putida CSV86-Identification of the Glucose-Binding Pocket by Homology-Model-Guided Site-Specific Mutagenesis. FEBS Journal, 281, 365-375. http://dx.doi.org/10.1111/febs.12607

[19] Bradford, M.M. (1976) A Rapid and Sensitive Method for the Quantitation of Microgram Quantities of Protein Utilizing the Principle of Protein-Dye Binding. Analytical Biochemistry, 72, 248-254.

[20] Laemmli, U.K. (1970) Cleavage of Structural Proteins during the Assembly of the Head of Bacteriophage T4. Nature, 227, 680-685. http://dx.doi.org/10.1038/227680a0

[21] Sly, L.M., Worobec, E.A., Perkins, R.E. and Phibbs, P.V. (1993) Reconstitution of Glucose Uptake and Chemotaxis in Pseudomonas aeruginosa Glucose Transport Defective Mutants. Canadian Journal of Microbiology, 39, 1079-1083. http://dx.doi.org/10.1139/m93-163

[22] Kabsch, W. (2010) XDS. Acta Crystallographica D, 66, 125-132. http://dx.doi.org/10.1107/S0907444909047337

[23] Winn, M.D., Ballard, C.C., Cowtan, K.D., Dodson, E.J., Emsley, P., Evans, P.R., Keegan, R.M., Krissinel, E.B., Leslie, A.G., McCoy, A., McNicholas, S.J., Murshudov, G.N., Pannu, N.S., Potterton, E.A., Powell, H.R., Read, R.J., Vagin, A. and Wilson, K.S. (2011) Overview of the CCP4 Suite and Current Developments. Acta Crystallographica D, 67, 235-242. http://dx.doi.org/10.1107/S0907444910045749

[24] Matthews, B.W. (1968) Solvent Content of Protein Crystals. Journal of Molecular Biology, 33, 491-497. http://dx.doi.org/10.1016/0022-2836(68)90205-2 